\title{
Generational Sub-cultures: Generation Y a Sub-culture?
}

\author{
Michelle Moss
}

Prof N. Martins

\author{
Department of Industrial and Organisational Psychology, University of South Africa
}

Martin @unisa.ac.za

\section{Doi:10.5901/mjss.2014.v5n21p147}

\section{Abstract}

The aim of this study was to determine (1) if there is a difference between Baby Boomers', Generation X's and Generation Y's perceptions of organisational culture and if so, (2) to determine if generational sub-cultures are formed within an organisation as a result of these different perceptions. A qualitative research design was utilised that sampled employees $(n=455)$ within a large South African ICT company who completed the South African Culture Instrument (SACI). The data was statistically analysed to determine employees' perceptions of organisational culture and to establish if generational sub-cultures exist within the organisation. This study indicates that generational sub-cultures can be identified within the organisation based on significantly different perceptions of five of the seven dimensions of organisational culture examined. Identifying generational sub-cultures within an organisation can lead to the development of an organisational talent management strategy for effectively attracting, managing and retaining generationally-diverse employees.

Keywords: Baby Boomers, Generation X, Generation Y, organisational sub-cultures.

\section{Introduction}

\subsection{Key focus of the study}

There is a perception that employees from different generational cohorts have varying expectations of the workplace (Lester, Standifer, Schultz \& Windsor, 2012). Understanding the similarities and differences in what employees value, what contributes to their engagement and in which organisational culture they will flourish has become a critical strategic business objective (Lundby, Lee, \& Macey, 2012) and one of the principal challenges facing managers today (Lester et al., 2012).

An organisation's culture, directly or indirectly, influences how individuals and groups think, act and respond within it (Shih \& Allen, 2007). Organisational culture may be made more complex by the presence of sub-cultures that exist independently of it and have their own distinct set of values, beliefs and attributes (Lok \& Crawford, 1999).

The key focus of this study is therefore to determine if there are indeed differences in the perceptions of organisational culture between three generational cohorts and, if so, to determine if this results in the formation of generational sub-cultures in the organisation.

\subsection{Background to the study}

As organisations grow and evolve, they form functional, geographical, ethnic and other kinds of groups, each of which exists in its own specific environment, and thus they begin to build their own sub-cultures (Martins \& Von de Ohe 2006; Schein 1990). Diversity and the integration of diverse viewpoints into organisations are also pertinent in the 21st-century world of shifting demographic patterns (Simons \& Rowland, 2011). This includes generational diversity, and today many organisations have up to four generations of employees working alongside each other (Lester et al., 2012). For organisations to effectively attract, manage and retain generationally diverse employees, it is helpful to understand if there are differences between the generations' perceptions of organisational culture and if generational sub-cultures are formed within the organisation as a result of these different perceptions. 


\subsection{Research objectives}

The objective of this study was to determine

(1) if there is a difference between Baby Boomers, Generation $X$ and Generation $Y$ employees' perceptions of organisational culture, and if so

(2) to determine if generational sub-cultures are formed within an organisation as a result of the different perceptions

\subsection{The concept of organisational culture}

\subsubsection{Organisational culture research}

In 1979, Pettigrew introduced concepts such as beliefs, ideology, language, rituals and myths which were widely used in sociology and anthropology and illustrated their applicability to organisational behaviour. He believed that these concepts were useful in understanding how organisational cultures are created. This sparked the interest of many academics and practitioners and the ensuing interest and dominant status that the "concept of culture" gained over the next few years was seen as a fad that would pass among managers, consultants and academics (Beyer \& Trice, 1987; Hofstede, Neuijen, Ohayv, \& Sanders, 1990). Interest did not wane, however, and instead led to the development of a plethora of different theories, models and frameworks aimed at explaining organisational culture as well as its impact on and relevance to organisations (Dauber, Fink, \& Yolles, 2012).

There are enormous variations in the definitions of organisational culture, especially since the concept lends itself to a broad variation of disciplines and research orientations such as anthropology, sociology, management studies, political science and industrial psychology (Alvesson, 2013). A sense of shared values and norms is a common thread in many definitions of organisational culture (Siehl \& Martin, 1983; Koberg \& Chusmir, 1987), but admitting that this is not a particularly rich conceptualisation of culture, other researchers have expanded the concept to include a common instrumental set of attitudes towards the activities and the settings people are engaged in, which serve as a foundation for an organisation's management system as well as the set of management practices and behaviours that both exemplify and reinforce those basic principles (Alvesson,1987; Denison, 1990).

Martins' (1989, 2006 p.92) definition based on Schein's (1990, p.111) work draws attention to the relationship between behaviour and the creation of organisational culture more clearly. He defined organisational culture as "an integrated pattern of human behaviour which is unique to a particular organisation and which originated as a result of the organisation's survival processes and interaction with its environment. Culture directs the organisation to goal attainment. Newly appointed employees must be taught what is regarded as the correct way of behaving".

Organisational culture is therefore viewed in this study as encompassing a system, or many systems, of deeplyrooted values and norms that are shared by employees and that direct their behaviour (Kinicki \& Kreitner 2009; Martins \& Martins 2004; Odendaal \& Roodt 1998). The concept of organisational sub-cultures as a system within a system is inferred in this definition.

\subsubsection{Models of organisational culture}

The single greatest challenge regarding organisational culture research has been the difficulty in establishing a single orienting paradigm by which research findings can be accumulated (Dauber et al., 2012; Moon, Quigley \& Carson-Marr, 2012).

Based on authors' definitions of organisational culture, various models have been developed and include elements such as beliefs, ideology, language, ritual and myth (Pettigrew,1970); symbols, heroes, rituals and values (Hofstede et al., 1990); artefacts, values and underlying assumptions (Schein, 1990); artefacts, values, assumptions, symbols linked by symbolisation, interpretation, manifestation and realisation (Hatch, 1993); history, values and beliefs, rituals and ceremonies, stories, heroic figures, the cultural network and corporate tribes (Deal \& Kennedy, 1982); and the organisational system, survival functions and dimensions of culture (Martins, 1989).

Martins' (1989) model encompasses all aspects of an organisation upon which organisational culture can have an influence, and vice versa (Martins, 1989). In addition, because Martins' (1989) model focuses on the dimensions of organisational culture rather than typologies, is applicable to the South African context and is aligned to this research study's overall paradigm perspective, it was chosen to form the foundation upon which this research study was based. 


\subsubsection{Sub-cultures}

The possibility that sub-cultures exist independently of organisational culture and that small groups within the organisation may have their own distinct set of values, beliefs, attributes, practices and behaviours has also been raised by many scholars and practitioners (Bellou, 2010; Lok \& Crawford, 1999).

Although there is some debate about the power and influence of the leader on creating organisational culture and sub-cultures (Schein, 1992; Martin \& Siehl, 1983) there is some agreement amongst researchers and practitioners regarding the sources of organisational sub-cultures. Suggestions include personal characteristics, personal biographies, positional characteristics, and task exigencies (Jermier, Slocum, Fry, \& Gaines, 1991); departmental groupings, geographical distribution, and the influence of a specific manager (Martins \& Von der Ohe, 2006); and shared experiences and the set-up of the organisation (Crough, 2012). Not all of these sources will necessarily form sub-cultures within an organisation, and Simons and Rowland (2011) make an important point that despite the presence or absence of sub-cultures, the organisation itself still serves as a point of connection for individuals and groups.

It is helpful to put the relationship between organisational culture and sub-cultures in perspective. Some scholars propose that the appearance of a singular organisational culture is reserved for the external public, while the internal reality of organisations is various interlocking, nested and sometimes conflicting sub-cultures (Jermier et al., 1991; Martin \& Siehl, 1983).

Lok, Westwood, and Crawford (2005) support this notion and comment that organisational culture as a construct applied to the whole of an organisation is useful in differentiating one organisation from another in inter-organisational studies, but it has limitations when trying to explain people's intra-organisational behaviour because of the complexity of sub-cultures present. This again highlights the need for researchers and practitioners to be clear on their area of focus, be it external or internal, when dealing with organisational culture and sub-cultures, and to adapt their approach accordingly in order to achieve optimal results. This research study adopts an intra-organisational focus.

\subsection{Generational research}

\subsubsection{Introduction}

Newspaper stories, consultant press releases, magazine articles and increasingly books are exhorting that there are different generational cohorts in the workforce that differ from each other in ways that are important for leaders and managers (Macky, Gardner \& Forsyth, 2008; Myers \& Sadaghiani, 2010). However, often such reports seem overly generalised and based either on anecdotal evidence or data not open to critical peer review (Macky et al., 2008).

\subsubsection{Generational cohort theory}

In 1974, Buss wrote about the importance of describing and explaining the theories around generational differences in order to gain an adequate understanding of generation-related social issues and problems. With four generations represented in the workplace for the first time, the study of generational dynamics in the workplace is taking on new significance and can be seen as one of the primary challenges currently facing managers ( Lester et al., 2012; Lundby et al., 2012).

The view of Foster (2013) is adopted in this study, namely that despite the ongoing debate over how to draw the boundaries and describe their contents, generations are conceptualised as a way of categorising people, even if only provisionally.

\subsubsection{Who are the generations?}

The three generations classified by Reynolds, Bush and Geist (2008) and used in this study are Baby Boomers (those born between 1946 and 1964), Generation X (those born between 1965 and 1981) and Generation Y (those born between 1982 and 2000). This is relevant to the field of industrial psychology because each generation is said to have social, economic, political and other contextual factors that shaped their values and beliefs about work (Real, Mitnick \& Maloney, 2010). A brief description of the perceived characteristics of the three generations follows:

(1) Baby Boomers are viewed as consensus seekers who are competitive micro-managers and possess a moderate level of disrespect for authority. (Kupperschmidt, 2000). They are seen as valuing collaboration and maintaining a somewhat formal organisational structure, placing workplace priorities over all non-work life, 
including family (Lester et al., 2012). Baby Boomers are currently the largest generational cohort in the workplace in most countries, and they are optimistic and value job security and a stable working environment (Wong, Gardiner, Lang, \& Coulon, 2008).

(2) Generation X are considered "latchkey kids" who grew up with financial, family and societal insecurity, rapid change, great diversity and a lack of solid traditions (Smola \& Sutton, 2002). Generally, they are seen as cynical, entrepreneurial and self-reliant (Kupperschmidt, 2000). Generation X bring to the workplace wellhoned, practical approaches to problem solving (Smola \& Sutton, 2002) and they are perceived to crave higher salaries, flexible work arrangements and more financial leverage (Smola \& Sutton, 2002). Generation X are seen as preferring technology-based interactions and avoiding unnecessary face-to-face meetings (Lester et al., 2012). They are disdainful of hierarchy and the word "boss" and they demand managers who are competent and both value and demand rewards and recognition (Kupperschmidt, 2000).

(3) Generation Y are also known as Millennials, Generation Me, Generation Whine, the Net Generation, Echo Boomers, iGeneration, Generation Why and Nexters. This generation are seen to have an entirely different work ethic, attitude and set of values shaking the foundation of workplaces and a growing body of evidence from around the world suggests the emergence of a youth culture that pervades national borders and is spurred by social media technology and communication advances( Lipkin \& Perrymore, 2009; Ng, Lyons, \& Schweitzer, 2012). They have been labelled self-centred, unmotivated, disrespectful, disloyal and contributing to widespread concern about how their communication will affect organisations and their relationships with other organisational members (Myers \& Sadaghiani, 2010). However, Generation Y have also been described as working well in teams, motivated to have an impact on the organisation, favouring open and frequent communication with their supervisors and at ease with communication technology (Myers \& Sadaghiani, 2010).

While anecdotal evidence continues to amass suggesting that Generation $Y$ are different, that they approach their working lives in a way that is novel and often at odds with the expectations placed on them by their Baby Boomer and Generation X bosses ( $\mathrm{Ng}$ et al., 2012), some empirical research seems to indicate that there are few or no significant differences, and the need to conduct further research, especially in an organisational context, is clear (Cennamo \& Gardner, 2008; Deal et al., 2010; Real et al., 2010).

\section{Research Design}

\subsection{Research approach}

System studies provide an appropriate framework for this study because they address the effectiveness and functionality of organisational systems and/or the relationship with the environment (Cunliffe, 2011). Lastly, in addition and also relevant to this study, is a descriptive, group-differences research approach which describes phenomena precisely and finds statistical significance between groups on a variable of interest. This design makes use of a classification and/or measuring of relationships (Terre Blanche et al., 2006).

\subsection{Research method}

\subsubsection{Research setting and variables}

This study was conducted within a large South African ICT company. The three generations of Baby Boomers, Generation $X$ and Generation $Y$ employees were defined and regarded as the independent variables. The dependent variables were the organisational cultural dimensions derived from the SACl and linked to Martins' (1999) model of organisational culture.

\subsubsection{Sampling procedure}

Proportional random stratified sampling was selected as the most appropriate sampling method for this study. This is a probability sampling technique whereby the researcher divides the total population into different sub-groups or strata and proceeds to randomly select the final subjects proportionally from the different strata (Teddlie \& Yu, 2007).

Stratified sampling was combined with random sampling in order to focus on specific sub-groups, namely generational cohorts, within the population and thus ensure the presence of the key generations within the sample. It also 
allowed the researcher to sample the rare extremes of the given population and this technique led to higher statistical precision compared to random sampling (Teddlie \& Yu, 2007). Since the strata used in this process were based on prespecified generational groups, there were no overlapping strata.

\subsubsection{Research participants}

Owing to cost, time and operational restrictions, only permanent employees from middle management levels and below were targeted $(\mathrm{N}=20771)$ and made up the population.

The response rate was ultimately $15.14 \%$ which yielded a total of 455 research participants with usable questionnaires. Of the respondents, Generation $X$ was the most represented at $54.5 \%$ of respondents, while $33.4 \%$ and $12.5 \%$ of respondents comprised Baby Boomers and Generation $Y$ respectively. Table 1 below provides a summary of the descriptive statistics in terms of the biographical and demographical profile of the respondents.

Table 1: Biographical and demographical profile of the respondents $(n=455)$

\begin{tabular}{llcc}
\hline Variable & Category & Frequency $(f)$ & Percentage $(\%)$ \\
\hline \multirow{2}{*}{ Gender } & Male & 322 & 70.8 \\
& Female & 133 & 29.2 \\
\multirow{4}{*}{ Race } & ffrican & 173 & 38.0 \\
& Coloured & 60 & 13.2 \\
& Indian & 42 & 9.2 \\
\multirow{4}{*}{ Generation } & White & 180 & 39.6 \\
& Baby Boomers & 152 & 33.4 \\
& Generation X & 248 & 54.5 \\
\multirow{3}{*}{ Level } & Generation Y & 55 & 12.1 \\
& Management & 35 & 7.7 \\
& Operational & 284 & 62.4 \\
& Specialist & 99 & 21.8 \\
& Supervisor & 37 & 8.1 \\
\hline
\end{tabular}

\subsubsection{The measuring instrument}

The South African Organisational Culture Instrument (SACI), developed by Martins (1989), was the primary measuring instrument used in this study. It has been scientifically and objectively proven valid and reliable (Martins \& Von der Ohe, 2006; Martins \& Coetzee, 2007) and was therefore appropriate for use in this study.

The instrument consisted of 89 items, but owing to operational time constraints imposed by the organisation, the questionnaire was shortened to 60 items that were representative of the seven dimensions of the original questionnaire. Respondents made use of a five-point Likert scale to rate each statement. All factors were scored such that a low score indicated non-acceptance of the cultural dimension, while a high score indicated acceptance (Martins \& Coetzee, 2007).

\subsubsection{Research procedure}

Informed consent was obtained from all the research participants and participants were reassured that participation was voluntary and they had the right to withdraw from the process at any time. It was explained that the risks associated with partaking in the study were minimal as participants remained anonymous and responses could not be traced back to any particular individual. The survey was electronically completed by participants via the organisation's private network which was accessible only to its employees. This contributed towards effective sample control and disallowed employees from forwarding the survey to external persons to complete (Simsek \& Veiga, 2001).

\subsubsection{Data analysis}

Descriptive statistics, factor and reliability analysis, and inferential statistics were measured using SPSS Version 20. The Kruskal Wallis test was used to identify possible significant differences between generational perceptions of the dimensions of organisational culture and to identify the presence of generational sub-cultures. 


\section{Results}

\subsection{Factor and reliability analysis for the SACI}

Because the SACI instrument used in this study was shortened to 60 items for operational reasons, a factor analysis was conducted to identify and confirm the dimensions which comprise organisational culture.

Table 2: The Kaiser-Meyer-Olkin (KMO) measure of sampling adequacy (MSA) and Bartlett's test of sphericity of the $\mathrm{SACl}$

\begin{tabular}{lcc}
\hline Kaiser-Meyer-Olkin measure of sampling adequacy & .9523 & 18352.356 \\
Bartlett's test of sphericity & Approx. chi-square & 1770 \\
& Df & 0.000 \\
\hline
\end{tabular}

As displayed in table 2 above, The Kaiser-Myer-Olkin value was 0.952 , therefore exceeding the recommended value of 0.6 (SPSS Version 20). Bartlett's test of sphericity reached statistical significance $(p=0.000)$ supporting the factorability of the correlation matrix.

Ten factors were postulated according to Kaiser's criterion and extracted by means of a principal component analysis. All components with an eigenvalue of less than 1 were eliminated, which resulted in a total of ten components.

The factor matrix obtained was rotated to simple structure by means of Varimax rotation. Factors with fewer than three items were eliminated because a factor with fewer than three items is generally considered weak and unstable (Costello \& Osborne, 2005). It was decided to retain seven factors for further investigation and analysis. Table 3 below provides reliability statistics for the questionnaire in terms of the Cronbach alphas for each dimension of organisational culture. Reliability statistics range from 0 to 1 , and an internal reliability coefficient of 0.70 or higher is deemed acceptable (Terre Blanche et al., 2006). The reliability coefficients for the seven dimensions ranged between 0.727 and 0.944 which is acceptable. In addition, the overall reliability was 0.967 , which is well within the recommended range.

\subsection{Descriptive statistics}

\subsubsection{Overall organisational culture results}

The organisational culture is described through the mean scores of the dimensions of organisational culture as displayed in table 3. In this study, an average of 3.2 is the reasonable cut-off point chosen to differentiate between positive and negative perceptions (Odendaal \& Roodt, 1998).

Table 3: Descriptive statistics and reliabilities of the SACI

\begin{tabular}{lcccccc}
\hline Dimension & N & Mean & Std deviation & Skewness & Kurtosis & Cronbach alphas \\
\hline Leadership & 455 & 3.54 & 0.84670 & -0.649 & -0.036 & 0.944 \\
Strategy and change management & 455 & 3.06 & 0.81108 & -0.358 & -0.411 & 0.914 \\
Employee needs & 455 & 2.83 & 0.86572 & -0.105 & -0.807 & 0.889 \\
Means to achieve objectives & 455 & 3.02 & 0.77416 & -0.248 & -0.514 & 0.862 \\
Management processes & 455 & 3.30 & 0.71433 & -0.388 & -0.195 & 0.860 \\
Organisational goals & 455 & 3.99 & 0.65500 & -0.697 & 1.360 & 0.727 \\
External and internal environment & 455 & 3.60 & 0.75434 & -0.442 & 0.184 & 0.790 \\
\hline
\end{tabular}

The majority of the dimensions have a mean of above 3.2, namely leadership (3.54), management processes (3.30), organisational goals (3.99) and external and internal environment (3.60). These dimensions of organisational culture were therefore perceived positively by the respondents.

The remaining three dimensions have means of below 3.2, and therefore it can be interpreted that respondents viewed these dimensions more negatively than the aforementioned dimensions.

The next section details the results of the Kruskal Wallis test calculated firstly at the dimension level and then at the item level of the SACl. 


\subsubsection{Results of dimensions and items}

Table 4 below provides a summary of the results of the means by generation per dimension. The dependent variables were not normally distributed, expect for one, and therefore a Kruskal-Wallis test, which is a non-parametric test, was used to identify possible significant differences between the three generations and the dimensions of organisation culture.

Table 4: Results of Kruskal-Wallis test for dimensions of organisational culture

\begin{tabular}{|c|c|c|c|c|c|c|}
\hline \multirow[t]{2}{*}{ Dimension } & \multicolumn{3}{|c|}{ Mean } & \multirow[t]{2}{*}{ Chi-square } & \multirow[t]{2}{*}{ df } & \multirow[t]{2}{*}{ Asymp. sig. } \\
\hline & Baby Boomers & Generation X & Generation Y & & & \\
\hline Leadership & 3.50 & 3.44 & 3.96 & 15.799 & 2 & $0.000^{*}$ \\
\hline Strategy and change management & 3.09 & 2.97 & 3.41 & 15.584 & 2 & $0.000^{*}$ \\
\hline Employee needs & 2.95 & 2.67 & 3.20 & 20.833 & 2 & $0.000^{*}$ \\
\hline Means to achieve objectives & 3.04 & 2.95 & 3.29 & 8.2575 & 2 & $0.016^{*}$ \\
\hline Management processes & 3.33 & 3.24 & 3.49 & 7.436 & 2 & $0.024^{*}$ \\
\hline Organisational goals & 3.94 & 4.00 & 4.09 & 5.698 & 2 & 0.058 \\
\hline External and internal environment & 3.59 & 3.58 & 3.72 & 2.453 & 2 & 0.293 \\
\hline
\end{tabular}

As reflected in table 4 above, the significance level is less than 0.05 for five of the seven dimensions. There is thus a statistically significant difference between the three generational cohorts with regard to the dimensions of leadership, strategy and change management, employee needs, means to achieve objectives and management processes.

Probing further, a comparison of the generational responses to each item of the SACl provides more insight into the organisational culture than simply examining the similarities and differences between the dimensions of organisational culture. Table 5 below indicates the items where statistically significant differences (where the significance level is less than 0.05 ) were found between generations.

Table 5: Kruskal-Wallis test: Comparison between generational cohorts and the dimensional items

\begin{tabular}{|c|c|c|c|c|c|c|c|}
\hline \multirow[t]{2}{*}{ Dimension } & \multirow[t]{2}{*}{ Abbreviated Statements } & \multicolumn{3}{|c|}{ Generation cohort means } & \multirow{2}{*}{$\begin{array}{l}\text { Chi- } \\
\text { square }\end{array}$} & \multirow[t]{2}{*}{ Df } & \multirow[t]{2}{*}{$\begin{array}{l}\text { Asymp } \\
\text { sig }\end{array}$} \\
\hline & & $\begin{array}{c}\text { Baby } \\
\text { Boomers }\end{array}$ & $\begin{array}{c}\text { Generation } \\
X\end{array}$ & $\begin{array}{c}\text { Generation } \\
Y\end{array}$ & & & \\
\hline \multirow[t]{9}{*}{ Leadership } & Sets an example & 3.56 & 3.48 & 3.98 & 8.312 & 2 & $.016^{\star}$ \\
\hline & Does a good job at people management & 3.56 & 3.52 & 3.93 & 6.735 & 2 & $.034^{*}$ \\
\hline & Is competent & 3.83 & 3.75 & 4.24 & 8.760 & 2 & $.013^{*}$ \\
\hline & Removes obstacles & 3.65 & 3.52 & 4.07 & 11.442 & 2 & $.003^{\star}$ \\
\hline & $\begin{array}{l}\text { Encourages subordinates to give their } \\
\text { opinion }\end{array}$ & 3.72 & 3.63 & 4.22 & 14.642 & 2 & $.001^{*}$ \\
\hline & Does a good job of managing the work & 3.78 & 3.55 & 4.02 & 11.184 & 2 & $.004^{*}$ \\
\hline & Have the necessary leadership skills & 3.30 & 3.21 & 3.87 & 16.926 & 2 & $.000 *$ \\
\hline & $\begin{array}{l}\text { Purposeful action to make contact with } \\
\text { employees }\end{array}$ & 3.09 & 2.94 & 3.85 & 26.522 & 2 & $.000^{\star}$ \\
\hline & Informs how new plans will affect work & 3.22 & 3.02 & 3.85 & 21.333 & 2 & $.000^{\star}$ \\
\hline \multirow[t]{5}{*}{$\begin{array}{l}\text { Strategy and change } \\
\text { management }\end{array}$} & $\begin{array}{l}\text { The vision to lead the company } \\
\text { successfully }\end{array}$ & 3.16 & 3.13 & 3.65 & 11.333 & 2 & $.003^{*}$ \\
\hline & $\begin{array}{l}\text { Keeps employees informed about the } \\
\text { strategy }\end{array}$ & 3.22 & 3.09 & 3.67 & 12.443 & 2 & $.002^{*}$ \\
\hline & $\begin{array}{l}\text { Takes purposeful action to integrate core } \\
\text { values }\end{array}$ & 3.37 & 3.27 & 3.65 & 6.340 & 2 & $.042^{\star}$ \\
\hline & The company is managed effectively & 2.80 & 2.69 & 3.31 & 14.085 & 2 & $.001^{*}$ \\
\hline & Those affected by decisions are consulted & 2.82 & 2.59 & 3.15 & 13.058 & 2 & $.001^{*}$ \\
\hline \multirow[t]{4}{*}{ Employee needs } & Remuneration is fair & 3.05 & 2.55 & 3.07 & 18.208 & 2 & $.000 *$ \\
\hline & Equal opportunities have become a reality & 2.80 & 2.34 & 2.80 & 16.109 & 2 & $.000^{*}$ \\
\hline & $\begin{array}{l}\text { Doing what it says regarding equal } \\
\text { opportunities }\end{array}$ & 2.76 & 2.41 & 2.82 & 10.803 & 2 & $.005^{\star}$ \\
\hline & Cares for it employees & 3.19 & 2.96 & 3.55 & 12.281 & 2 & $.002^{\star}$ \\
\hline
\end{tabular}




\begin{tabular}{|c|c|c|c|c|c|c|c|}
\hline & Trust relationship exists & 2.91 & 2.67 & 3.29 & 15.370 & 2 & $.000^{*}$ \\
\hline & Contribution in identifying outputs & 3.09 & 2.79 & 3.31 & 12.909 & 2 & $.002^{*}$ \\
\hline \multirow{3}{*}{$\begin{array}{l}\text { Means to achieve } \\
\text { objectives }\end{array}$} & Recruitment without discrimination & 2.78 & 2.71 & 3.49 & 19.594 & 2 & $.000^{*}$ \\
\hline & Activities of divisions are coordinated & 2.93 & 2.84 & 3.29 & 7.864 & 2 & $.020^{*}$ \\
\hline & Performance evaluated objectively & 3.02 & 2.87 & 3.45 & 14.062 & 2 & $.001^{*}$ \\
\hline \multirow{3}{*}{$\begin{array}{l}\text { Management } \\
\text { processes }\end{array}$} & Ensure the success of change & 3.22 & 3.12 & 3.58 & 10.714 & 2 & $.005^{*}$ \\
\hline & Retain best workers & 2.70 & 2.54 & 3.00 & 8.992 & 2 & $.011^{*}$ \\
\hline & Delegate power & 3.24 & 3.18 & 3.58 & 8.555 & 2 & $.014^{*}$ \\
\hline \multirow[t]{2}{*}{$\begin{array}{l}\text { External and internal } \\
\text { environment }\end{array}$} & $\begin{array}{l}\text { Satisfied with the company's involvement } \\
\text { in the community }\end{array}$ & 3.56 & 3.69 & 3.91 & 6.469 & 2 & $.039 *$ \\
\hline & Shares success with the community & 3.53 & 3.56 & 3.89 & 8.013 & 2 & $.018^{*}$ \\
\hline
\end{tabular}

${ }^{*} \mathrm{P}<0.05$

The results of the dimensions are discussed below in more detail:

\subsubsection{Leadership}

The results indicate that all three generations overall have a positive perception of leadership in the organisation. There were significant differences in the degree of positivity between the generations. Generation $Y$ indicated greater agreement than Generation X or Baby Boomers sets an example that can be followed, takes purposeful action to make contact with employees at lower levels, is competent and that managers know their jobs, try to remove obstacles that occur in the work environment, have the necessary leadership skills, inform employees timeously of how new plans and changes will affect their work, and encourage subordinates to give their opinion about work matters.

There were no significant differences between the generations in their perception that they are afforded the opportunity to present their ideas to leadership, that there is sufficient personal discussion of significant matters between employees and leadership and that they solve their differences.

\subsubsection{Strategy and change management}

Overall this dimension was viewed negatively by Generation $X$ and Baby Boomers, but positively by Generation $Y$. Generation $Y$ gave the highest ratings of the three generations in terms of their perceptions and were alone in their view that the organisation's executive management has the vision and knowledge to lead the company successfully, that the company is managed effectively and that employees are kept informed about the strategy of the company.

All three generations concurred that the company takes purposeful action to integrate core values with all activities and results.

Although all three generations had a negative perception that when decisions are made at higher levels those most affected by these decisions are consulted, there was a significant difference in the degree of negativity with which they rated this item.

However, there were no significant differences between the generational cohorts in their perception that change is a well-planned process in the organisation and their negative view that the company does not respond quickly to changes in the environment.

\subsubsection{Employee needs}

This dimension was viewed overall in a negative light by all three generational cohorts, although there were significant differences between the generations' responses on seven of the eight items of the employee needs dimension.

Although viewed negatively, the Generation $Y$ respondents were significantly more positive that remuneration is fair, equal opportunities for all people in the company have become a reality; the company is doing what it says about equal opportunities for all employees; a visible trust relationship exists between employees and management; and recruitment takes places without discrimination in terms of gender, race or language.

Generation Y had a significantly different perception that the company cares for its employees and that employees are afforded the opportunity to make a contribution in identifying the outputs of their own division, whereas Generation $\mathrm{X}$ and Baby Boomers viewed these items more negatively. 
There was no significant difference between the three generations' perception that there is openness in the company on matters that are important to employees.

\subsubsection{Means to achieve objectives}

Baby Boomers and Generation X had a negative perception of this dimension and there were significant differences between two of the nine responses.

The significant differences between the three generations was evident in their perception that activities of the various divisions are coordinated and aligned and performance/achievement is evaluated objectively according to actual results. In both these instances Generation Y respondents were the most positive cohort.

There were no significant differences between the generational cohorts in terms of their negative perception that the system is overloaded with unnecessary paperwork, duplication of work occurs, conflict between divisions in the organisation causes a waste of resources, conflict is not resolved by those involved, and management does not believe that subordinates are self-motivated and have the ability to control their own work.

\subsubsection{Management processes}

This dimension was viewed positively overall by all three generational cohorts although there were significant differences between their perceptions of three of the eight items of this dimension.

There were significant differences between the generations' perceptions that management does their best to ensure the success of change, the organisation retains its best workers and those in positions of authority delegate as much power as is required to complete tasks successfully.

There were no significant differences in the generations' perceptions that rules and regulations are continuously reviewed and upgraded to cope with change; employees are encouraged to develop better work procedures and methods; the achievement of goals is considered important and therefore enough time is spent on implementation; employees are committed to change and that this will improve the company; and that management and employees collectively formulate objectives.

\subsubsection{Organisational goals}

All three generations perceived goals positively and there was no significant difference between their responses. This suggests that they all perceived that their own personal goals can be satisfied through the achievement of organisational goals, and that they fully understand the mission and overall objectives of the organisation.

\subsubsection{External and internal environment}

There were no significant differences between the generational cohorts in terms of their positive perception of this dimension. However, there were significant differences in their responses to two of the four items. Although all positive, the three generations had significantly different perceptions that the company shares its success with the community and that they were satisfied with the company's involvement in the community.

There were no significant differences between their positive perceptions that the company's Employment Equity strategy has been clearly communicated to them and that they understand this strategy.

\section{Discussion}

Identifying, understanding and addressing generational sub-cultures amongst employees in the 21st-century world of work is becoming increasingly important if organisations wish to effectively attract, manage and retain talent and compete on a global level. The main contribution of this study at a practical level was therefore to identify the possible existence of generational sub-cultures within an organisation. If generational sub-cultures are present, then the need to develop an organisational talent strategy for effectively attracting, managing and retaining generationally diverse employees is imperative. Contrary to recent empirical studies that show mixed results (Parry \& Urwin, 2011) or no significant differences between the generations (Real et al., 2010; Twenge, 2010), the results of this study indicate that there are significant differences in the way generations view five of the seven dimensions of organisational culture and as a result generational sub-cultures are formed within the organisation. 
The results indicate a clear trend of Generation $Y$ providing the highest ratings for almost all items, Generation $X$ providing the lowest, and Baby Boomers in-between. This supports popular literature that characterises Generation $X$ as typically more cynical and Generation $\mathrm{Y}$ as typically more positive, optimistic or even somewhat idealistic about the world of work (De Hauw \& De Vos, 2010; Gibson et al., 2009; Lipkin \& Perrymore, 2009).

\subsection{Leadership}

There was a significant difference between the three generational cohorts' view of leadership although all three cohorts experienced leadership positively. Murray, Toulson, and Legg (2011) comment that while all employees may value a supportive leader, the expectations of the way this is manifested in the workplace may differ between the generations.

Myers and Sadaghiani (2010) discuss the traditional practice for leaders to communicate with other leaders within the workplace and not subordinates. It is therefore interesting that the results of this study indicate that employees from all three generational cohorts feel they are afforded the opportunity to present their ideas to leadership and are encouraged to give their opinions on work matters, and there are no significant differences between the generational cohorts in this regard.

\subsection{Strategy and change management}

The results indicate there were no significant differences between the generational cohorts in their perception that change is a well-planned process in the organisation and their negative view that the company does not respond quickly to changes in the environment. This implies that all employees believed the company does not respond quickly to change and only Generation Y espoused change as a well-planned process.

In their study, Martins and Von der Ohe (2006) proposed that the more strategic or long-term focused dimensions of organisational culture may have the greatest influence on the creation of sub-cultures. The results of this study indicated significant overall differences between the perceptions of the generations with regard to strategy and change management and confirm the creation of generational sub-cultures based on this more strategic and long-term focused dimension.

\subsection{Employee needs}

Overall, this dimension was also viewed negatively by all three generational cohorts, although there were significant differences between the generations' responses on seven of the eight items of the employee needs dimension.

In terms of employee needs, $\mathrm{Ng}$, Schweitzer and Lyons (2010) discuss the popular view that the career-related expectations of Generation $Y$ are "supersized", unrealistic and disconnected from reward and performance. The responses given by Generation $Y$ in this study were higher than Generation $X$ or Baby Boomers for most of the items. Regarding the fairness of salary and fringe benefits, however, all three generations viewed this in a negative light. The recent global economic downturn may be responsible for all three generations lowering their expectations and not Generation Y alone, as expected (De Hauw \& De Vos, 2010).

\subsection{Means to achieve objectives}

Baby Boomers and Generation $X$ have an overall negative perception of this dimension and there are significant differences between the cohorts' responses to the items.

Hershatter and Epstein (2010) discuss the popular view that Generation Y are a "demanding workforce", "high maintenance" or "needy" in their demand for structure, reassurance and feedback on performance. They are said to experience a large amount of angst when expected to work with ambiguity, without guidelines, templates, or examples, because they are not used to performing without explicit instructions, well-defined criteria for success, and specific deadlines set by others (Hershatter \& Epstein, 2010). At the same time, Generation Y are said to be extremely sensitive to negative feedback and criticism, and this is likely to affect their perceptions of how fairly performance is rated (Lipkin \& Perrymore, 2009). It is interesting therefore that Generation $Y$ have a positive perception that performance is evaluated objectively based on actual results, whereas Generation $X$ and Baby Boomers view this in an extremely negative light. The organisation in which this study was conducted is large and traditionally bureaucratic, with set structures, procedures and guidelines for success. The results may therefore indicate that Generation $Y$ find that these supporting structures suit their preferences for clarity and feedback, whereas Generation X and Baby Boomers find this more tedious, restrictive 
and frustrating (Hershatter \& Epstein, 2010).

\subsection{Management processes}

Latham's (2009) study emphasises the benefit of participation in formulating objectives and goal setting as having a positive effect on performance to the extent that it increases self-efficacy and the discovery of task relevant strategies. This relationship is not moderated by age, however (Latham, 1991), which could explain why there were no significant differences between the cohorts in this regard.

Cardy and Lengnick-Hall (2011) acknowledge that if the best workers are not retained, an organisation can be negatively affected from the operational to the strategic level. Their research provides a model for organisations to influence employee retention based upon the value of employees to the organisation and is not generation specific which aligns to the findings of this study.

In their study, Martins and Von der Ohe (2006) found that sub-cultures were created based on management processes. Although this related mostly to differences in the way things were done between regions, the results of the current study indicated that generational sub-cultures are also formed based on significant differences in the way generational cohorts view management processes.

\subsection{Organisational goals and objectives}

All three generational cohorts perceived organisational goals positively and there were no significant differences between their responses. Kupperschmidt (2000) discusses the need for today's multi-generational leaders and managers to bring employees together in ways that provide fair and equitable opportunities for each individual to contribute their best and to achieve personal goals in alignment with organisational goals.

\subsection{External and internal environment}

There were no significant differences between the generational cohorts in terms of their positive ratings of this dimension.

In their empirical study, $\mathrm{Ng}$ et al. (2010) found that Generation $\mathrm{Y}$ rated social responsibility and commitment to diversity as the most important factor. It is interesting therefore that in this study, all three generations viewed the organisation's commitment to diversity and involvement in the community positively and with no significant difference between them. Perhaps this can be explained in part by the transformation agenda in South Africa following the 1994 elections (Oosthuizen \& Naidoo, 2010), in which awareness of diversity, employment equity policies and social responsibility are promoted by law and prioritised in the South African workplace. This could also explain why generational sub-cultures are not formed based on differing perceptions of this dimension of organisational culture.

\section{Conclusion}

Based on the results above, the first objective (there are significant differences between Baby Boomers, Generation $X$ and Generation Y employees' perceptions of organisational culture) is accepted as the three generations do view most of the dimensions of organisational culture differently. It can also be concluded that generational sub-cultures are created within the organisation based on differing perceptions of the mentioned dimensions, the second objective (generational sub-cultures have formed within the organisation based on the generational cohorts' different perceptions of organisational culture) can be accepted.

The findings of this study indicated that generational sub-cultures can be identified on the basis of five of the seven dimensions of organisational culture examined. In summary it appears as if organisations need to take note of the similarities between the generations and maintain the strategies for focusing on these. However, organisations need to take note of the different expectations and needs of especially Generation $Y$ which is developing into a separate subculture.

\section{Limitations}

This study has limitations. This study was conducted within one organisation and the culture questionnaire was adapted for use in this context. It is thus possible that the findings might not be generally applicable to other organisations and contexts. 
This study was conducted using quantitative methods without a supportive qualitative phase such as conducting focus groups to verify the data. The concept of generations is complex and the cross-sectional design of this study was a limitation (Arsenault, 2004). A longitudinal study would make it possible to determine whether differences between generations are as a result of age, career stage, life stage or genuine generational differences (Cennamo \& Gardner, 2008; Meriac et al., 2010; Parry \& Urwin, 2011).

\section{Recommendations}

Although there are some empirical studies on generational cohorts, much of the literature is anecdotal. There is mixed support for the existence of generational differences, and more empirical research would be required to substantiate or refute these popular perceptions.

In addition, further studies could examine the relationship between differing human resources practices and the formation of organisational sub-cultures (Palthe \& Kossek, 2002). The influence of the South African transformation agenda on generational cohorts and organisational sub-cultures could also be examined in more depth.

The results of this research indicate there is evidence to support the development of talent management strategies aimed at effectively attracting, managing and retaining the generationally diverse workforce currently present in the workplace, focusing especially on Generation Y.

\section{References}

Alvesson, M. (2013). Understanding organizational culture (2nd ed.). London: Sage.

Arsenault, P. M. (2004). Validating generational differences: A legitimate diversity and leadership issue. Leadership and Organization Development Journal, 25(2), 124-141.

Bellou, V. (2010). Organizational culture as a predictor of job satisfaction: The role of gender and age. Career Development International, 15(1), 4-19.

Beyer, J. M., \& Trice, H. M. (1987). How an organization's rites reveal its culture. Organizational Dynamics, 15(4), 5-24.

Buss, A. R. (1974). Generational analysis: Description, explanation and theory. Journal of Social Issues, 30(2), 55-71.

Cardy, R.L., \& Lengnick-Hall, M.L. (2011). Will they stay or will they go? Exploring a customer-oriented approach to employee retention. Journal of Business and Psychology, 26(2), 213-217.

Cennamo, L., \& Gardner, D. (2008). Generational differences in work values, outcomes and person-organisation values fit. Journal of Managerial Psychology, 23(8), 891-906.

Costello, A. B., \& Osborne, J. W. (2005). Best practices in exploring factor analysis: Four recommendations for getting the most from your analysis. Practical Assessment, Research and Evaluation, 10(7), 1- 9.

Crough, D. (2012). The identification and influence of organisational sub-cultures on organisational outcomes. Unpublished DLitt et Phil (Industrial and Organisational Psychology) thesis. Parkway, Michigan, University of Nebraska: ProQuest LLC.

Cunliffe, A. L. (2011). Crafting qualitative research: Morgan and Smircich, 30 years on. Organizational Research Methods, 14(4), 647673.

Dauber, D., Fink, G., \& Yolles, M. (2012). A configuration model of organizational culture. Sage Open, 2(1), 1-33.

De Hauw, S., \& De Vos, A. (2010). Millennials' career perspective and psychological contract expectations: Does the recession lead to lowered expectations? Journal of Business Psychology, 25, 293-302.

Deal, J. J., Altman, D. G., \& Rogelberg, S. G. (2010). Millennials at work: What we know and what we need to do (if anything). Journal of Business Psychology, 25, 191-199.

Deal, T. E., \& Kennedy, A. A. (1982). Corporate cultures: The rites and rituals of corporate life. Boston, MA: Addison-Wesley.

Denison, D. R. (1990). Corporate culture and organizational effectiveness. New York: Wiley.

Foster, K. (2013). Generation and discourse in working life stories. The British Journal of Sociology, 64(2), 195-215.

Gibson, J. W., Greenwood, R. A., \& Murphy, E. F. (2009). Generational differences in the workplace: Personal values, behaviours, and popular beliefs. Journal of Diversity Management, 4(3), 1-8.

Hatch, M. J. (1993). The dynamics of organizational culture. The Academy of Management Review, 18(4), 657-693.

Hershatter, A., \& Epstein, M. (2010). Millennials and the world of work: An organization and management perspective. Journal of Business Psychology, 25, 211-223.

Hofstede, G., Neuijen, B., Ohayv, D., \& Sanders, G. (1990). Measuring organizational cultures: A qualitative and quantitative study across twenty cases. Administrative Science Quarterly, 35(2), 2896-316.

Jermier, J. M., Slocum, J. W., Fry, L. W., \& Gaines, J. (1991). Organizational subcultures in a soft bureaucracy: Resistance behind the myth and facade of an official culture. Organization Science, 2(2), 170-194.

Kinicki, A., \& Kreitner, R. (2009). Organizational Behaviour: Key concepts, skills and best practices. New York: McGraw-Hill Irwin.

Koburg, C., \& Chusmir, L. (1987). Organizational culture relationships with creativity and other job-related variables. Journal of Business Research, 15(5), 397-409.

Kupperschmidt, B. R. (2000). Multi-generation employees: Strategies for effective management. Health Care Manager, 19(1), 65-76. 
Latham, G. P. (1991). Self-regulation through goal setting. Organizational Behaviour and Human Decision Processes, 50(2), $212-247$.

Latham, G. P. (2009). Motivate employee performance through goal setting. In E. A. Locke (Ed.), Handbook of principles of organizational behaviour (2nd ed.). West Sussex: Wiley.

Lester, S. W., Standifer, R. L., Schultz, N. J., \& Windsor, J. M. (2012). Actual versus perceived generational differences at work: An empirical examination. Journal of Leadership and Organizational Studies, 19(3), 341-354.

Lipkin, N. A., \& Perrymore, A. J. (2009). Y in the workplace: Managing the me first generation. Franklin Lakes: Career Press.

Lok, P., \& Crawford, J. (1999). The relationship between commitment and organizational culture, subculture, leadership style and job satisfaction in organizational change and development. Leadership and Organization Development Journal, 20(7), 365-374.

Lok, P., Westwood, R., \& Crawford, J. (2005). Perceptions of organisational subculture and their significance for organisational commitment. Applied Psychology: An International Review, 54(4), 490-514.

Lundby, K., Lee, W., \& Macey, W. (2012). Leadership essentials to attract, engage and retain global human talent. In W. Mobley, Y. Want, \& M. Li (Eds.), Advances in Global Leadership (Vol. 7, pp. 251-270). Emerald Group.

Macky, K., Gardner, D., \& Forsyth, S. (2008). Generational differences at work: Introduction and overview. Journal of Managerial Psychology, 23(8), 857-861.

Martin, J., \& Siehl, C. (1983). Organizational culture and counterculture: An uneasy symbiosis. Organizational Dynamics, $12(2), 52-64$.

Martins, N. (1989). Organisasiekultuur in 'n finansiele instelling. Ongepubliseerde DPhil-proefskrif. Pretoria: University of Pretoria.

Martins, N., \& Coetzee, M. (2007). Organisational culture, employee satisfaction, perceived leader emotional competency and personality type: An exploratory study in a South African Engineering Company. South African Journal of Human Resources Management, 5(2), 20-32.

Martins, N., \& Martins, E. C. (2004). Organisational culture. In S. O. Robbins, \& G. Roodt (Eds.), Organisational behaviour: Global and Southern African perspectives. Cape Town: Pearson Education South Africa.

Martins, N., \& von der Ohe, H. (2006). Detecting sub-cultures in an organisation. Southern Africa Business Review, 10(2), $130-149$.

Moon, H., Quigley, N. R., \& Carson-Marr, J. (2012). How interpersonal motives explain the influence of organisational culture on organisational productivity, creativity and adaptation: The ambidextrous interpersonal motives (AIM) model of organizational culture. Organizational Psychology Review, 2(2), 109-128.

Murray, K., Toulson, P., \& Legg, S. (2011). Generational cohorts' expectations in the workplace: A study of New Zealanders. Asia Pacific Journal of Human Resources, 49(4), 476-493.

Myers, K. K., \& Sadaghiani, K. (2010). Millennials in the workplace: A communication perspective on millennials' organizational relationships and performance. Journal of Business Psychology, 25, 225-238.

Ng, E. S., Lyons, S. T., \& Schweitzer, L. (Eds.). (2012). Managing the new workforce: International perspectives on the millennial generation. Boston, MA: Edward Elgar.

Ng, E. S., Schweitzer, L., \& Lyons, S. T. (2010). New generation, great expectations: A field study of the millennial generation. Journal of Business Psychology, 25, 281-292.

Odendaal, A., \& Roodt, G. (1998). Corporate culture and participation: Independent constructs? Journal of Industrial Psychology, 24(3), 14-21.

Oosthuizen, R. M., \& Naidoo, V. (2010). Attitudes towards and experience of employment equity. SA Journal of Industrial Psychology, 36(1), 1-9.

Palthe, J., \& Kossek, E. E. (2003). Subcultures and employment modes: Translating HR strategy into practice. Journal of Organizational Change Management, 16(3), 287-308.

Parry, E., \& Urwin, P. (2011). Generational differences in work values: a review of theory and evidence. International Journal of Management Reviews, 13, 79-96.

Pettigrew, A. M. (1979). On studying organizational cultures. Administrative Science Quarterly, 24, 570-581.

Real, K., Mitnick, A. D., \& Maloney, W. F. (2010). More similar than different: Millennials in the US building trades. Journal of Business Psychology, 25, 303-313.

Reynolds, L., Bush, E. C., \& Geist, R. (2008). The Gen Y imperative. Communication World, 25(2), 19-22.

Savaneviciene, A. \& Stankeviciute, Z. (2011). The interaction between top management and line managers. Engineering Economics, 22(4), 412-422

Schein, E. H. (1990). Organizational culture. American Psychologist, 45(2), 109-119.

Schein, E. H. (1992). Organizational culture and leadership. San Francisco: Jossey-Bass.

Shih, W., \& Allen, M. (2007). Working with generation D: Adopting and adapting to cultural learning and change. Library Management, 28(1), 89-100.

Siehl, C., \& Martin, J. (1983). Organizational culture and counter culture: An uneasy symbiosis. Organizational Dynamics, $12(2), 52-64$.

Simons, S., \& Rowland, K. (2011). Diversity and its impact on organisational performance: The influence of diversity constructions on expectations and outcomes. Journal of Technology Management and Innovation, 6(3), 171-182.

Smola, K., \& Sutton, C. (2002). Generational differences: Revisiting generational work values for the new millennium. Journal of Organizational Behaviour, 23, 363-382.

Teddlie, C., \& Yu, F. (2007). Mixed methods sampling: A typology with examples. Methods Research, 1, 77-100.

Terre Blanche, M., \& Durrheim, K. (2006). Histories of the present: Social science research in context. In M. Terre Blanche, K. Durrheim, \& D. Painter (Eds.), Research in practice: Applied methods for the social sciences (2nd ed.). Cape Town: University of Cape Town Press. 
Tredoux, C., \& Durrheim, K. (2005). Numbers, hypothesis and conclusions: A course in statistics for the social sciences. Cape Town: Cape Town University Press.

Twenge, J. M. (2010). A review of the empirical evidence on generational differences in work attitudes. Journal of Business Psychology, $25,201-210$.

Twenge, J. M., \& Campbell, S. M. (2008). Generational differences in psychological traits and their impact on the workplace. Journal of Managerial Psychology, 23(8), 862-877.

Wiant, C. (1999). Are you listening to your employees. Journal of Environmental Health, 62(3), 51-52.

Wong, M., Gardiner, E., Land, W., \& Coulon, L. (2008). Generational differences in personality and motivation. Journal of Managerial Psychology, 23(8), 878-890. 